\title{
PERANCANGAN SISTEM INFORMASI MANAJEMEN STOK MAKANAN PADA RESTORAN BUBUR AYAM DOPLANGAN
}

\author{
Dhanang Tias Anggoro', Rulin Yunestri ${ }^{2}$, Shafirah Nurlita Chaniago ${ }^{3}$ \\ ${ }^{1,2,3}$ Program Studi Akuntansi, Fakultas Ekonomi, Universitas Tulungagung \\ Jl. Ki Mangunsarrkoro, Beji, Kab. Tulungagung 66233
}

Telp. (0355) 322145

Email:xsclman@gmail.com ${ }^{1}$, rulinyunestri89@gmail.com ${ }^{2}$, chaniagoshafirah@gmail.com ${ }^{3}$

\begin{abstract}
The sales management process at the Doplangan Chicken Porridge restaurant, food stock control is still manual, so it has an impact on frequent inaccuracies and delays in the menu ordering process. This happens because of the absence of a computer-based system that can facilitate customers in ordering menus, calculating the amount of payments at the cashier, and the management having difficulty in making sales reports that make it difficult to make decisions. This study was made to design a client-server based stock management information system to monitor food stock at the Doplangan Chicken Bubur restaurant more easily and automatically. This menu ordering system uses a mobile application on the customer side and a desktop application on the kitchen. The application development method used is the Rapid Application Development (RAD) method, with the Unified Modeling Language (UML) object-oriented software design. To test this research design, it is assumed that a customer places an order when the food stock in the kitchen runs out. The result is that the system installed in the kitchen will display a notification message that the stock will run out. Thus, the kitchen section can add stock so that the menu stock is always available and there are no more customers who feel annoyed and disappointed.
\end{abstract}

Keywords: restaurant, information system, sales, stock management, management information system, RAD, UML. 


\begin{abstract}
ABSTRAK
Proses manajemen penjualan pada restoran Bubur Ayam Doplangan, pengendalian stok makanan masih bersifat manual, sehingga berdampak pada sering terjadinya ketidakakuratan dan keterlambatan proses pemesanan menu. Hal ini terjadi karena ketiadaan sebuah sistem berbasis komputer yang dapat memudahkan pelanggan dalam pemesanan menu, penghitungan jumlah pembayaran di bagian kasir, dan pihak manajemen mengalami kesulitan dalam pembuatan laporan penjualan yang menyulitkan pengambilan keputusan. Penelitian ini dibuat untuk merancang suatu sistem informasi manajemen stok berbasis client-server untuk memantau stok makanan pada restoran Bubur Ayam Doplangan dengan lebih mudah dan otomatis. Sistem pemesanan menu ini menggunakan aplikasi mobile pada sisi pelanggan dan aplikasi desktop pada bagian dapur. Metode pengembangan aplikasi yang digunakan adalah metode Rapid Application Development (RAD), dengan desain perangkat lunak berorientasi objek Unified Modeling Language (UML). Untuk menguji rancangan penelitian ini diasumsikan seorang pelanggan melakukan pemesanan ketika stok makanan di dapur akan habis. Hasilnya pada sistem yang terpasang pada bagian dapur akan memunculkan pesan pemberitahuan bahwa stok akan habis. Dengan demikian, bagian dapur dapat melakukan penambahan stok sehingga stok menu selalu tersedia dan tidak ada lagi pelanggan yang merasa kesal dan kecewa.
\end{abstract}

Kata kunci: restoran, sistem informasi, penjualan, manajemen stok, sistem informasi manajemen, RAD, UML. 


\section{PENDAHULUAN}

Perkembangan bisnis yang terjadi dewasa ini tidak terlepas dari peran teknologi. Dimana salah satu manfaat dari penggunaan teknologi tersebut adalah kemampuannya dalam mengakomodir hampir seluruh informasi penting setiap perusahaan kepada pelanggan, pemasok, dan karyawan. Akan tetapi tidak jarang pula masih sering ditemukan perusahaan maupun organisasi yang masih menggunakan cara bisnis tradisional dalam mengelola dan menjalankan bisnisnya. Namun cara bisnis tradisional ini dianggap lambat, baik dalam pengolahan data, pemprosesan data maupun setiap terjadi perubahan data, karena setiap data atau informasi harus diperbaiki secara manual.

Aplikasi yang akan dibahas pada penelitian ini adalah aplikasi manajemen restoran. Dimana aplikasi ini menawarkan kemudahan dalam pengolahan data. Setiap usaha kuliner seperti restoran sering kali dihadapkan pada masalah pengendalian stok makanan, terutama karena kurangnya informasi yang mendukung pengambilan keputusan. Salah satu penyebabnya adalah kurang memadainya sistem pencatatan transaksi yang berhubungan dengan pemesanan.

Pada restoran Bubur Ayam Doplangan, selama ini penjual harus bolak-balik untuk mengecek ketersediaan menu yang dipesan oleh pelanggan restoran terutama pada saat menu akan habis. Tentunya hal tersebut sangat merepotkan, terutama pada jam-jam ramai saat banyak pelanggan yang harus ditanganinya. Akibat dari keterbatasan tersebut kemungkinan kelalaian pada penjual sangat bisa terjadi, terutama pada pencatatan ketersediaan stok makanan yang ada di restoran tersebut. Apabila terjadi masalah seperti kehabisan stok makanan, pelanggan pasti merasa kesal karena stok pesanannya habis. Untuk itulah diperlukan suatu sistem yang memberikan informasi stok makanan. Dengan adanya sistem ini diharapkan akan mempermudah dalam mengecek stok makanan.

Manajemen persediaan merupakan salah satu aset yang paling mahal, mencerminkan sebanyak $40 \%$ dari total modal yang diinvestasikan. Perusahaan dapat mengurangi biaya dengan cara menurunkan tingkat persediaan ditangan. Dilain pihak, konsumen akan merasa tidak puas bila suatu produk stoknya habis. Oleh karena itu, perusahaan harus mencapai keseimbangan di antara keduanya

Diharapkan dengan adanya penelitian ini tingkat kepuasan pelanggan terhadap restoran Bubur Ayam Doplangan semakin membaik. Pelanggan atau konsumen adalah semua orang yang menuntut kita untuk memenuhi suatu standar kualitas 
tertentu, dan karena itu akan memberikan pengaruh pada performasi kita atau perusahaan.

Karena fokus dari kualitas adalah kepuasan pelanggan, maka perlu dipahami komponen-komponen yang berkaitan dengan pelanggan. Pada dasarnya, kepuasan pelanggan dapat didefinisikan secara sederhana sebagai suatu keadaan di mana kebutuhan, keinginan, dan harapan pelanggan dapat terpenuhi melalui produk yang dikonsumsi.(Prabowo, 2016)

Band dalam Nasution (2004:49) menyatakan secara sederhana definisi pelanggan sebagai berikut:"Satisfaction in the state in which costumer need, wants and expectations, throught the transaction cycle, are not exceeded, resulting in repurchase and continuingloyalty. In other words, if costumer satisfaction could be expressed as a ratio, it would look like this : customer satisfaction $=$ precieved quality : needs, wants, and expectation."

Definisi kepuasan dari Band di atas, merumuskan kepuasan pelanggan sebagai perbandingan antara kualitas dari barang atau jasa yang dirasakan dengan keinginan, kebutuhan dan harapan pelanggan. Lebih lanjut Band mengemukakan, apabila tercapai kepuasan pelanggan, maka akan timbul pembelian ulang dan kesetiaan.(Prabowo, 2016)

Pada penelitian ini membahas tentang perancangan sistem informasi manajemen stok berbasis client-server pada, pada restoran Bubur Ayam Doplangan di mana pada sisi pelanggan menggunakan aplikasi mobile dan pada bagian dapur menggunakan aplikasi desktop. Perbedaan lainnya adalah pada sistem informasi manajemen stok yang dirancang ini memiliki sistem peringatan, yang akan memberitahukan kepada bagian dapur ketika stok makanan akan habis. 


\section{LANDASAN TEORI}

\subsection{Tujuan Sistem Informasi}

Teknologi informasi banyak membawa perubahan dalam organisasi dan proses bisnis. Teknologi informasi merupakan suatu kebutuhan bagi organisasi yang dapat membantu kinerja organisasi dan individu. Sistem informasi akan membantu perusahaan untuk menyajikan laporan keuangan ke dalam bentuk informasi yang akurat dan terpercaya, sehingga banyak pihak yang memanfaatkan sistem informasi akuntansi untuk mencapai keunggulan bagi perusahaan. Sistem informasi adalah komponen dan elemen dari suatu organisasi yang menyediakan informasi bagi pengguna dengan pengolahan peristiwa keuangan.

Tujuan dari sistem informasi adalah menghasilkan informasi. Informasi adalah data yang diolah menjadi bentuk yang berguna bagi para pemakainya. Untuk dapat berguna maka informasi harus didukung oleh tiga pilar sebagai berikut: tepat kepada orangnya atau relevan, tepat waktu dan tepat nilainya atau akurat. Keluaran yang tidak didukung oleh tiga pilar ini tidak dapat dikatakan sebagai informasi yang berguna. Untuk menjadi sistem informasi, maka hasil dari sistem itu harus berupa informasi yang berguna, yaitu harus memenuhi ketiga kriteria: relevan, tepat waktu dan akurat. (Purnama, 2016)

\subsection{Pentingnya Sistem Informasi Manajemen}

Keberhasilan suatu organisasi dalam mencapai tujuannya sangat tergantung pada kemampuan orang yang mengelola organisasi tersebut. Manajemen sebagi suatu metode yang mengatur, mengelola organisasi dapat diartikan sebagai seni melaksanakan sesuatu melalui orang. Jika manajemen suatu organisasi baik maka akan meningkatkan kemakmuran suatu negara.

Dalam menjalankan tugasnya, para manajer memerlukan informasi, karena adanya perbedaan tugas maka informasi yang diperlukan juga akan berbeda. Perbedaan tersebut disebabkan oleh adanya periode waktu, tingkat ketidakpastian, tipe informasi, dasar kebutuhan informasi dan bentuk pelaporan. Sehingga dapat dikategorikan bahwa informasi adalah salah satu jenis sumberdaya utama, dan termasuk dalam kategori sumberdaya konseptual.

Jenis sumberdaya utama lainnya, dalam kategori sumberdaya fisik, yaitu; manusia, material, mesin (termasuk fasilitas dan energi) dan uang. Sumberdaya fisik yang berada pada organisasi biasanya terbatas dan bisa habis atau punah. Sedangkan sumberdaya informasi bersifat "tidak" akan pernah habis. Sehingga semua 
sumberdaya, baik fisik maupun konseptual harus disinergikan. Oleh karena itu tugas dari manajer adalah mengarahkan penggunaan semua sumberdaya agar dapat dimanfaatkan secara efektif.

Sebagai tindak lanjut dari tugas manajer tersebut, maka perlu adanya usaha penataan sumberdaya (Manajemen Sumberdaya) termasuk didalamnya manajemen informasi, yakni:

- Sumberdaya harus disusun sedemikian rupa sehingga setiap saat diperlukan dapat segera dimanfaatkan - perlu dilakukan modifikasi

- Sumberdaya harus dimanfaatkan semaksimal mungkin

- Sumberdaya harus selalu diperbaharui

Manajer memastikan bahwa data mentah yang diperlukan terkumpul dan kemudian diproses menjadi informasi yang berguna. Kemudian manajer memastkan bahwa orang yang layak dalam organisasi menerima informasi tersebut dalam bentuk yang tepat pada saat yang tepat sehingga informasi tersebut dapat dimanfaatkan. Akhirnya manajer membuang informasi yang tidak berguna lagi dan menggantikannya dengan informasi yang terkini dan akurat. Seluruh aktivitas tersebut (memperoleh informasi, menggunakannya seefektif mungkin dan membuangnya pada saat yang tepat, disebut sebagai manajemen informasi.(Purnama, 2016)

\subsection{Peranan Sistem Informasi Manajemen}

Pada awalnya, pemakai output komputer pada perusahaan adalah pegawai administrasi di bagian akuntansi, yang komputernya melaksanakan aplikasi seperti pembayaran gaji pegawai, pengelolaan persedian (inventory control), dan penagihan. Sebagian informasi juga disediakan bagi para manajer, tetapi hanya sebagai output tambahan dari aplikasi akuntansi.(Purnama, 2016)

Gagasan untuk menggunakan komputer sebagai sistem informasi manajemen (SIM) merupakan suatu terobaosan besar, karena menyadari bahwa para manajer memerlukan informasi untuk pemecahan masalah. Ketika perusahaan-perusahaan menjangkau konsep SIM, mereka mulai mengembangkan berbagai aplikasi yang secara khusus diarahkan untuk mendukung manajen. Namun, bukan hanya manajemen yang memperoleh manfaat dari penerapan SIM. Nonmanajer dan staf ahli juga menggunakan outputnya. Selain itu juga dimanfaatkan oleh para pemakai yang berada di luar perusahaan, yaitu para pelanggan akan menerima faktur dan laporan 
transaksinya, para pemegang saham akan menerima cek deviden, dan pemerintah akan menerima laporan pajak. Dengan demikian secara ringkas para pengguna dan pelaku sistem informasi meliputi: manajer, non-manajer dan orang dan unit organisasi yang ada dalam organisasi dan lingkungannya.

Dalam pembahasan pada materi SIM, yang akan dibahas lebih lanjut adalah para pelaku dan pemakai dari kelompok manajer. Keberadaan manajer bisa kita saksikan ada di mana-mana diberbagai tingkat dan dalam berbagai bidang fungsional pada perusahaan.

Manajer Dijumpai pada Semua Jenjang, sesuai dengan tingkatan manajemen, yaitu :

- Tingkat Perencanaan Strategis (Strategic planning level) adalah merupakan manajer pucak organisasi. Mereka mempunyai pengaruh atas keputusankeputusan yang diambil pada seluruh organisasi selama beberapa tahun mendatang. Istilah lain yang digunakan yakni eksekutif.

- Tingkat Pengendalian Manajemen (Management control level) adalah merupakan manajer tingkat menengah, yang memiliki tanggung jawab untuk merubah rencana menjadi tindakan dan memastikan agar tujuannya tercapai.

- Tingkat Pengendalian Operasional (Operational conrol level) adala merupakan manajer tingkat bawah, yang bertangung jawab menyelesaikan rencanarencana yang telah ditetapkan oleh para manajer ditingkat yang lebih tinggi.

Selain keberadaan manajer itu ada di berbagi tingkatan organisasi atau perusahaan. Manajer juga dijumpai dalam bidang fungsional perusahaan, tempat berbagai sumberdaya dipisahkan menurut jenis pekerjaan yang dilakukan. Pembagian bidang fungsional pada umunya yaitu seperti:

- Bidang fungsional keuangan (Finance)

- Bidang fungsional jasa informasi (Information services)

- Bidang fungsional pemasaran (Marketing)

- Bidang fungsional sumberdaya manusia (Human resources)

- Bidang fungsional manufaktur (Manufacturing) 


\section{Misi Sistem Informasi:}

Memperbaiki kinerja orang-orang yang ada di dalam organisasi dengan memanfaatkan teknologi informasi.

\section{Tujuan Sistem Informasi:}

Perbaikan kinerja organisasi (performance improvement)

\subsection{Manfaat Sistem Informasi Manajemen}

Supaya informasi yang dihasilkan oleh sistem informasi dapat berguna bagi manajamen, maka analis sistem harus mengetahui kebutuhan-kebutuhan informasi yang dibutuhkannya, yaitu dengan mengetahui kegiatan - kegiatan untuk masingmasing tingkat (level) manajemen dan tipe keputusan yang diambilnya. Berdasarkan pada uraian di atas, maka terlihat bahwa tujuan dibentuknya Sistem Informasi Manajemen atau SIM adalah supaya organisasi memiliki informasi yang bermanfaat dalam pembuatan keputusan manajemen, baik yang meyangkut keputusan - keputusan rutin maupun keputusan - keputusan yang strategis.(Purnama, 2016)

Sehingga SIM adalah suatu sistem yang menyediakan kepada pengelola organisasi data maupun informasi yang berkaitan dengan pelaksanaan tugas-tugas organisasi.

Beberapa manfaat atau fungsi sistem informasi antara lain adalah sebagai berikut:

- Meningkatkan aksesibilitas data yang tersaji secara tepat waktu dan akurat bagi para pemakai, tanpa mengharuskan adanya prantara sistem informasi.

- Menjamin tersedianya kualitas dan keterampilan dalam memanfaatkan sistem informasi secara kritis.

- Mengembangkan proses perencanaan yang efektif.

- Mengidentifikasi kebutuhan-kebutuhan akan keterampilan pendukung sistem informasi.

- Menetapkan investasi yang akan diarahkan pada sistem informasi.

- Mengantisipasi dan memahami konsekuensi-konsekuensi ekonomis dari sistem informasi dan teknologi baru.

- Memperbaiki produktivitas dalam aplikasi pengembangan dan pemeliharaan sistem. 
- Organisasi menggunakan sistem informasi untuk mengolah transaksitransaksi, mengurangi biaya dan menghasilkan pendapatan sebagai salah satu produk atau pelayanan mereka.

- Bank menggunakan sistem informasi untuk mengolah cek - cek nasabah dan membuat berbagai laporan rekening koran dan transaksi yang terjadi.

\subsection{Industri Restoran}

Menurut Chew, industri restoran merupakan sebuah bagian terintegerasi kondisi eksternal memiliki pengaruh yang cukup besar. Untuk itu diperlukan proses adaptasi dengan cepat baik dari sisi manajerial atau teknologi sehingga restoran dapat meningkatkan performa pelayanan kepada pelanggan.(Fania et al., 2015)

\subsection{Manajemen Restoran}

Manajemen restoran adalah kemampuan untuk mengatur jalannya kegiatan bisnis dalam mengelola sebuah restoran. Dibutuhkan 3 pengguna utama sehingga sebuah manajemen restoran dapat dikatakan memiliki kualitas yang baik, yaitu :

- Pengguna yang bertugas pada bagian administrasi

- Pengguna yang bertugas di bagian depan

- Pengguna yang bertugas di bagian belakang

Seorang pemilik restoran, direktur operasional dapat dikategorikan sebagai pengguna yang bertugas pada bagian administrasi. Kasir, pelayan, supervisor pelayan adalah contoh pengguna yang bertugas di bagian depan. Kepala koki beserta koki adalah pengguna yang bertugas di bagian belakang.

Dengan memiliki manajemen restoran yang baik, diharapkan kualitas pelayanan yang diterima pelanggan lebih baik sehingga meningkatkan kepuasan pelanggan. Salah satu kualitas yang diperlukan dalam operasional restoran adalah pelayanan yang baik dan kecepatan dalam pelayanan.(Fania et al., 2015)

\subsection{Manajemen Stok}

Manajemen Stok adalah segala sesuatu/sumber daya organisasi yang disimpan dalam antisipasinya terhadap pemenuhan permintaan.(Indrajit \& Djokopranoto, 2003)

Meliputi:

- Persediaan bahan mentah

- Persediaan barang dalam proses

- Persediaan barang jadi/produk akhir

- Persediaan bahan-bahan pembantu/pelengkap 
- Persediaan komponen-komponen lain yang menjadi bagian keluaran produk perusahaan

- Uang

- Ruangan fisik (bangunan)

- Peralatan

- Tenaga kerja

\subsection{Sistem Pengendalian Stok}

Merupakan serangkaian kebijakan pengendalian utk menentukan: tingkat persediaan yg harus dijaga, kapan pesanan utk menambah persediaan harus dilakukan, \& berapa besar pesanan harus diadakan.

Sistem ini ada utk menentukan dan menjamin tersedianya persediaan yg tepat dalam kuantitas \& waktu. (Indrajit \& Djokopranoto, 2003)

\subsection{Definisi RAD (Rapid Application Development)}

Adalah seperangkat teknik terintegrasi, pedoman dan tools yang memfasilitasi kebutuhan sistem perangkat lunak pelanggan dalam waktu singkat. Jangka waktu yang telah ditetapkan ini disebut timebox. Produk perangkat lunak tidak muncul pada akhir siklus pengembangan, melainkan berkembang selama proses pembangunan RAD berdasarkan umpan balik pelanggan.(Yen \& Davis, 1998)

\subsection{Unified Modelling Language (UML)}

Unified Modelling Language (UML) adalah sebuah "bahasa" yg telah menjadi standar dalam industri untuk visualisasi, merancang dan mendokumentasikan sistem piranti lunak. UML menawarkan sebuah standar untuk merancang model sebuah sistem.

Dengan menggunakan UML kita dapat membuat model untuk semua jenis aplikasi piranti lunak, dimana aplikasi tersebut dapat berjalan pada piranti keras, sistem operasi dan jaringan apapun, serta ditulis dalam bahasa pemrograman apapun. Tetapi karena UML juga menggunakan class dan operation dalam konsep dasarnya, maka ia lebih cocok untuk penulisan piranti lunak dalam bahasa-bahasa berorientasi objek seperti $\mathrm{C}++$, Java, C\# atau VB.NET. Walaupun demikian, UML tetap dapat digunakan untuk modeling aplikasi prosedural dalam VB atau C.

Seperti bahasa-bahasa lainnya, UML mendefinisikan notasi dan syntax/semantik. Notasi UML merupakan sekumpulan bentuk khusus untuk menggambarkan berbagai diagram piranti lunak. Setiap bentuk memiliki makna 
tertentu, dan UML syntax mendefinisikan bagaimana bentuk-bentuk tersebut dapat dikombinasikan. Notasi UML terutama diturunkan dari 3 notasi yang telah ada sebelumnya: Grady Booch OOD (Object-Oriented Design), Jim Rumbaugh OMT (Object Modeling Technique), dan Ivar Jacobson OOSE (Object-Oriented Software Engineering).

Sejarah UML sendiri cukup panjang. Sampai era tahun 1990 seperti kita ketahui puluhan metodologi pemodelan berorientasi objek telah bermunculan di dunia. Diantaranya adalah: metodologi booch, metodologi coad, metodologi OOSE, metodologi OMT, metodologi shlaer-mellor, metodologi wirfs-brock, dsb. Masa itu terkenal dengan masa perang metodologi (method war) dalam pendesainan berorientasi objek. Masing-masing metodologi membawa notasi sendiri-sendiri, yang mengakibatkan timbul masalah baru apabila kita bekerjasama dengan group/perusahaan lain yang menggunakan metodologi yang berlainan.(Dharwiyanti \& Wahono, 2003) 


\section{METODE PENELITIAN}

Metode dalam penelitian ini menggunakan Metode Pengembangan Perangkat Lunak Rapid Application Development (RAD) yaitu model proses pengembangan perangkat lunak yang bersifat incremental terutama untuk waktu pengerjaan yang pendek.

Untuk metode pengumpulan data dilakukan dengan Observasi, wawancara dan studi pustaka.

Untuk analisis dan perancangan menggunakan diagram UML yang terdiri atas diagram kelas, diagram sequence dan diagram aktivitas. Sedangkan untuk rancang bangun aplikasi menggunakan Bahasa pemrograman PHP dan database MYSQL

\section{PEMBAHASAN}

Analisis kebutuhan merupakan proses yang pertama kali dilakukan untuk menghasilkan spesifikasi kebutuhan dari sistem yang akan dirancang. Spesifikasi kebutuhan adalah spesifikasi yang rinci tentang pengolahan data yaitu jumlah data yang harus diproses. Pada sistem informasi manajemen stok restoran Bubur Ayam Doplangan yang dirancang ini, analisis kebutuhan yang dilakukan meliputi kebutuhan fungsional dan nonfungsional.

Dimana Kebutuhan fungsional meliputi fungsi-fungsi yang harus dapat dilakukan oleh sistem informasi manajemen stok restoran Bubur Ayam Doplangan, yaitu:

a. Sistem dapat memberi peringatan jika stok bahan makan akan habis.

b. Admin dapat melakukan penambahan, pengeditan, dan penghapusan data bahan makanan dan minuman pada sistem informasi manajemen stok makanan dan minuman restoran.

c. Sistem dapat meminimalkan terjadinya kehabisan stok barang sehingga tidak terjadi yang namanya stok kosong atau habis.

Sedangkan Kebutuhan nonfungsional merupakan kebutuhan sistem meliputi performa, kelengkapan operasi pada fungsi-fungsi yang ada, dan kesesuaian dengan lingkungan penggunanya. Adapun kebutuhan nonfungsional pada perancangan sistem informasi manajemen stok restoran Bubur Ayam Doplangan adalah:

a. Kebutuhan perangkat keras untuk aplikasi desktop (server)

1) Processor : Intel Dual Core @ $2.0 \mathrm{GHz}$ 
2) Harddisk : $320 \mathrm{~GB}$

3) Memory :2048 MB

4) VGA : $128 \mathrm{MB}$

5) Monitor : LCD 15"

6) Mouse

7) Keyboard

b. Kebutuhan perangkat lunak untuk aplikasi desktop (server)

1) Java NetBeans

2) PHP

3) MySQL

4) Web Service

5) Java Plugin Android

6) OS Windows 7

c. Kebutuhan perangkat lunak untuk aplikasi mobile (client)
1) Versi OS Android : 7.1 .2 (Nougat)
2) Tipe processor $\quad: 1.4 \mathrm{GHz}$ quad core
3) RAM :2 GB

d. Kebutuhan sumber daya manusia (brainware), berupa admin yang mampu menjalankan komputer. 


\subsection{Rancangan Fungsional}

Setelah dilakukan proses analisis kebutuhan, maka dibuat model proses dari sistem informasi manajemen stok yang akan dirancang. Dalam penelitian ini, digunakan metode UML untuk menggambarkan proses bisnis yang terjadi di restoran Bubur Ayam Doplangan. Unified Modeling Language (UML) adalah bahasa untuk menspesifikasi, memvisualisasikan, serta mengontruksikan bangunan dasar sistem perangkat lunak, termasuk melibatkan pemodelan aturan-aturan bisnis. Salah satu model di dalam UML adalah diagram use case yang merupakan pemodelan untuk tingkah laku (behavior) sistem informasi yang akan dibuat. Pada sistem informasi manajemen stok restoran Bubur Ayam Doplangan ini terdapat 2 aktor, yaitu pelanggan dan dapur, berikut ini use case diagram dari pelanggan dan dapur yang ditunjukkan pada Gambar 1 dan Gambar 2.

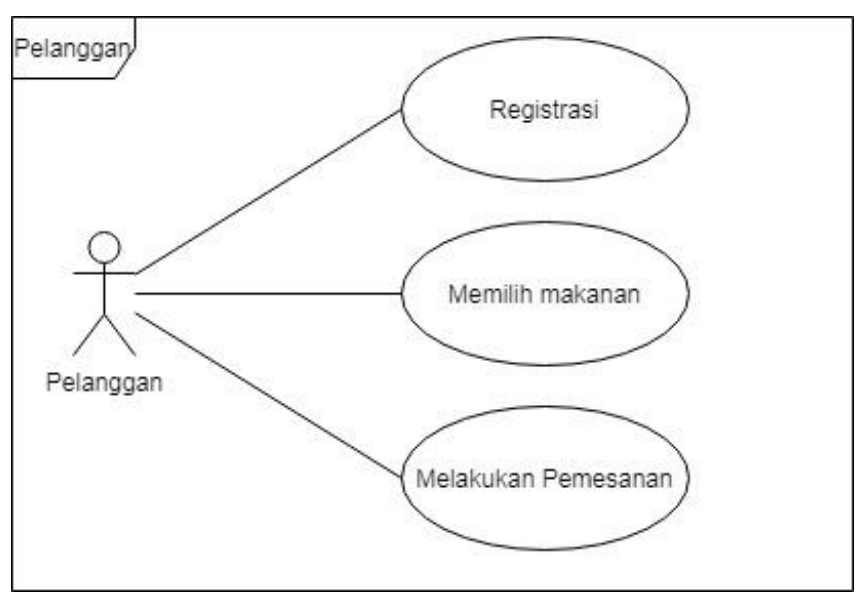

Gambar 1. Diagram Use Case Pelanggan

Gambar 1 menunjukkan diagram use case pelanggan pada sistem informasi manajemen stok restoran Bubur Ayam Doplangan. Pada diagram tersebut terdapat 3 aktivitas yang akan dijelaskan pada Tabel 1 berikut:

\begin{tabular}{|c|l|l|}
\hline No. & \multicolumn{1}{|c|}{ Use Case } & \multicolumn{1}{c|}{ Deskripsi } \\
\hline 1 & Registrasi & Melakukan pengisian data pelanggan dan nomor meja \\
\hline 2 & Memilih makanan & Pelanggan memilih makanan yang akan dipesan \\
\hline 3 & Melakukan pemesanan & $\begin{array}{l}\text { Pelanggan melakukan validasi terhadap makanan dan } \\
\text { minuman yang dipesan. }\end{array}$ \\
\hline
\end{tabular}




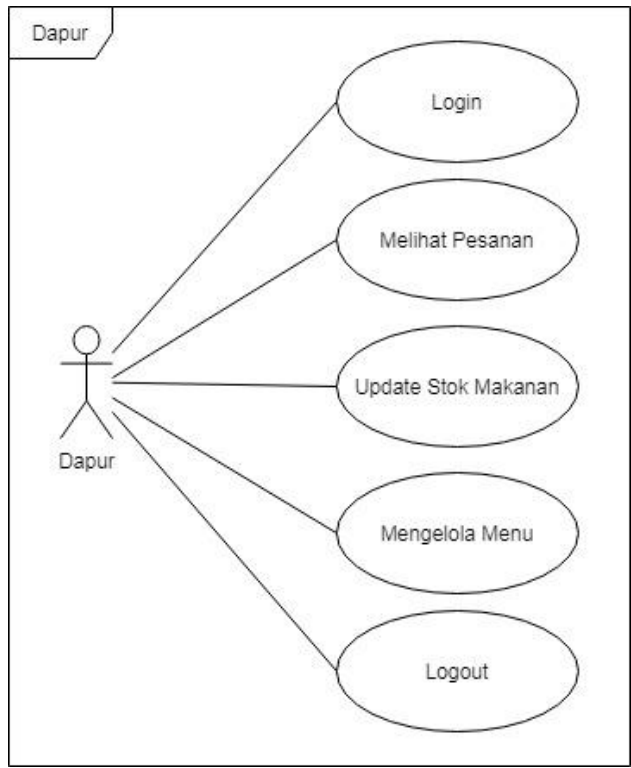

Gambar 2. Diagram Use Case Bagian Dapur

Gambar 2 menunjukkan diagram use case bagian dapur pada sistem informasi manajemen stok di restoran Bubur Ayam Doplangan. Pada diagram use case tersebut terdapat 5 aktivitas yang akan dijelaskan pada Tabel 2 berikut:

\begin{tabular}{|c|l|l|}
\hline No. & \multicolumn{1}{|c|}{ Use Case } & \multicolumn{1}{c|}{ Deskripsi } \\
\hline 1 & Login & $\begin{array}{l}\text { Pengguna melakukan login untuk masuk } \\
\text { sistem }\end{array}$ \\
\hline 2 & Melihat Pesanan & Pengguna melihat detail pesanan pelanggan \\
\hline 3 & Update Stok Makanan & Pengguna melakukan update stok makanan \\
\hline 4 & Mengelola Menu & $\begin{array}{l}\text { Pengguna melakukan penambahan, } \\
\text { penghapusan, dan mengubah data menu }\end{array}$ \\
\hline 5 & Logout & Pengguna keluar dari sistem \\
\hline
\end{tabular}

Pada rancangan sistem ini dibuat peringatan, yaitu jika stok makanan atau minuman kurang dari atau sama dengan 5 (lima), maka sistem akan menampilkan pesan pemberitahuan pada sistem informasi manajemen stok yang terpasang di dapur. Sehingga sistem peringatan ini akan mengingatkan pihak dapur untuk melakukan penambahan stok makanan ataupun minuman. Hal inilah yang menjadi kelebihan dari sistem informasi manajemen stok restoran Bubur Ayam Doplangan sehingga stok makanan selalu tersedia dan tidak akan ada lagi pelanggan yang merasa kesal dan kecewa karena menu yang dipesan pelanggan akan selalu tersedia. 


\subsection{Rancangan Prototype}

Setelah penggambaran model proses, tahap selanjutnya dalam perancangan sistem informasi manajemen stok pada restoran Bubur Ayam Doplangan ini adalah penggambaran model antarmuka.

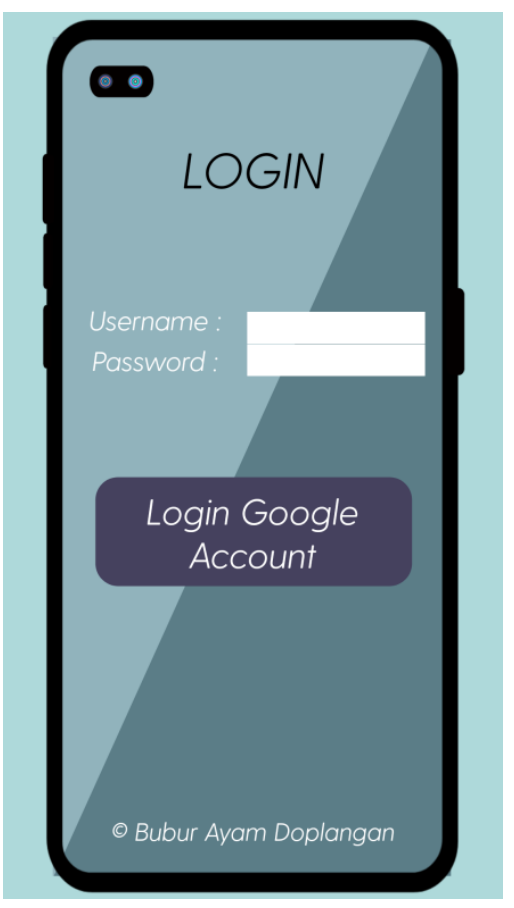

Gambar 3. Halaman Login Aplikasi Mobile

Gambar 3 merupakan tampilan halaman login dari sisi pelanggan yang menggunakan perangkat mobile. Pemakai atau end user dapat melakukan login dengan memasukkan username dan password, ataupun menggunakan akun Google. 


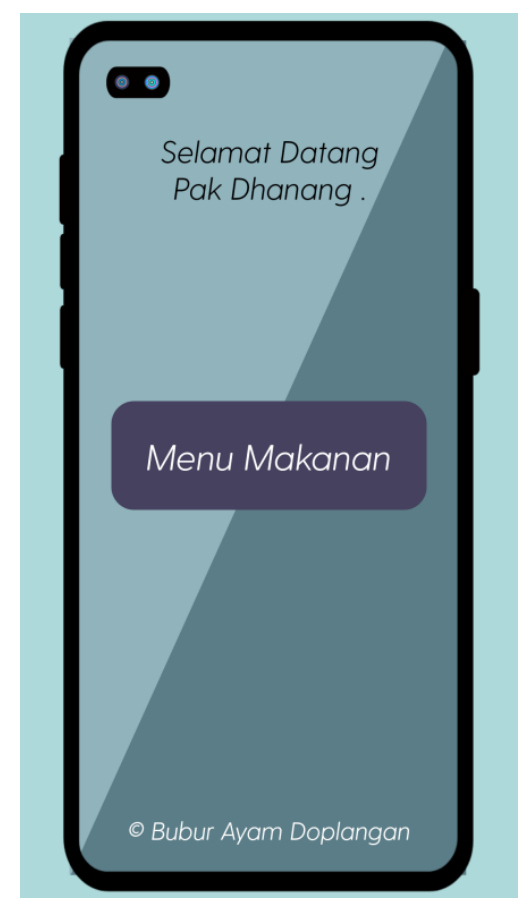

\section{Gambar 4. Halaman Menu Utama Aplikasi Mobile}

Gambar 4 merupakan tampilan menu utama aplikasi mobile setelah pelanggan melakukan login. Di sini pelanggan dapat memilih menu makanan.

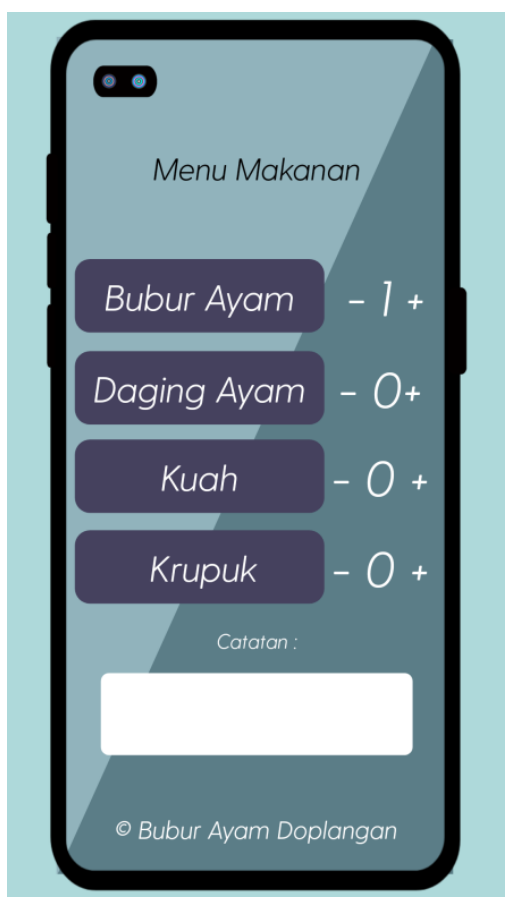

Gambar 5. Tampilan Menu Makanan Aplikasi Mobile

Gambar 5 merupakan contoh tampilan menu makanan yang dapat dipilih pelanggan melalui perangkat mobile. Di sini terdapat beberapa pilihan menu makanan yang bisa dipilih dengan cara mengklik salah satu menu, misalnya klik "Bubur Ayam", maka akan muncul tampilan seperti pada Gambar 6. 


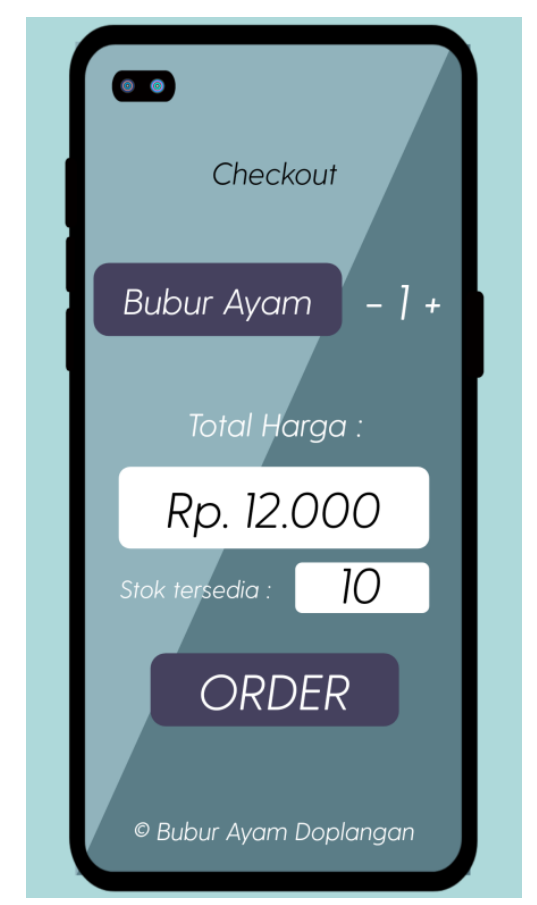

Gambar 6. Halaman Menu Order

Pada Gambar 6 dapat dilihat bahwa di dalam menu checkout (pembayaran) terdapat informasi harga dan stok yang tersedia, serta pelanggan dapat memasukkan dan mengubah jumlah pesanannya dan mengklik "Order".

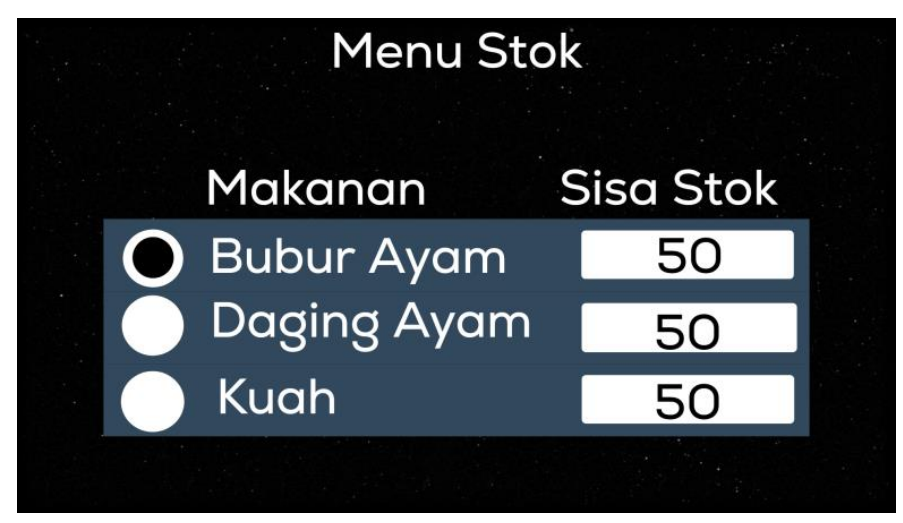

Gambar 7. Menu Stok Makanan Aplikasi Desktop

Gambar 7 merupakan contoh tampilan menu stok makanan yang terdapat di bagian dapur, yang berbasis desktop. Aplikasi di bagian dapur ini berfungsi untuk memantau jumlah stok yang tersisa.

Pada sistem informasi manajemen stok makanan yang dirancang ini terdapat sistem peringatan. Seperti pada Gambar 8, peringatan sisa stok akan muncul apabila sisa stok kurang dari atau sama dengan 5. 


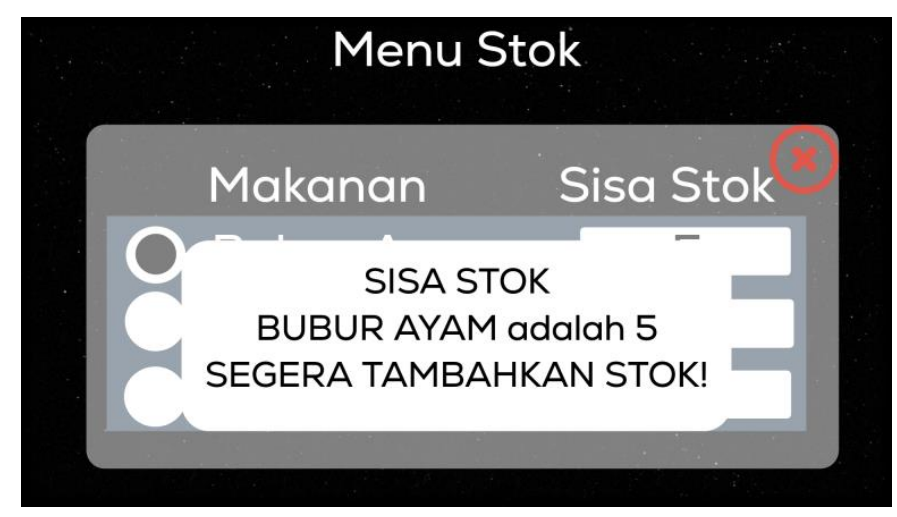

Gambar 8. Peringatan Sisa Stok

Selanjutnya, setelah menerima pesan peringatan, karyawan pada bagian dapur akan melakukan penambahan stok makanan. Dalam hal ini, karyawan bagian dapur dapat memperbarui data stok. Di dalam menu stok, pengguna dapat menambahkan ataupun mengurangi stok makanan sesuai ketersediaan bahan yang ada di dapur. Tampilannya dapat dilihat pada Gambar 9.

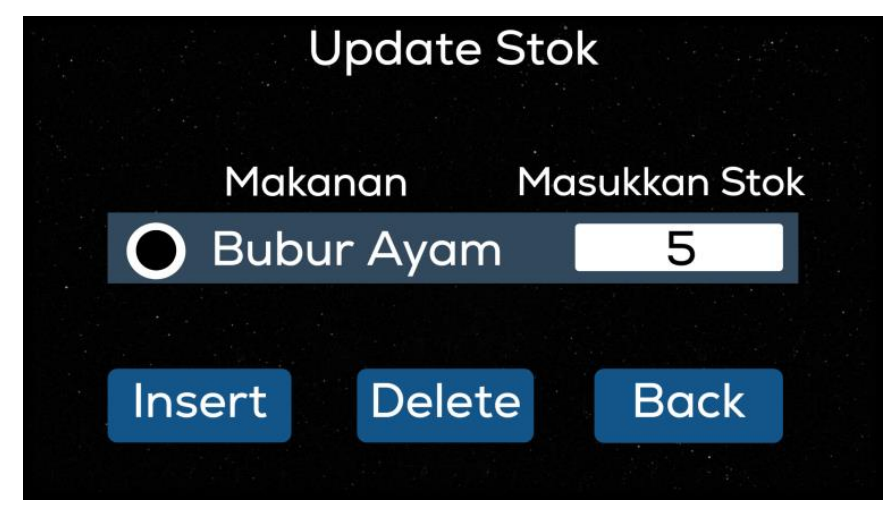

Gambar 9. Menu Update Stok

Dari semua prototype tersebut dapat dilihat bahwa diasumsikan seorang pelanggan melakukan pemesanan 1 paket Bubur Ayam ketika stok Bubur Ayam di dapur tersisa 6 buah. Saat melakukan pemesanan tersebut, maka stok Bubur Ayam di dapur akan berkurang menjadi 5 buah. Sehingga, pada sistem yang terpasang pada bagian dapur muncul suatu pesan pemberitahuan bahwa stok akan habis, yang kemudian pihak dapur akan melakukan penambahan stok. 


\section{KESIMPULAN DAN SARAN}

Perancangan sistem informasi manajemen stok pada penelitian ini menghasilkan sistem peringatan yang akan memberitahukan kepada bagian dapur ketika stok makanan yang tersedia akan habis sehingga pihak restoran dapat melakukan penambahan stok dengan segera.

Saran yang dapat diambil dari Penelitian ini adalah sebagai berikut:

1. Sistem manajemen restoran memiliki banyak aspek untuk dikembangkan seperti integrasi dengan sistem manajemen karyawan.

2. Perlu dilakukan penelitian lebih lanjut agar fitur-fitur pada aplikasi dapat ditambah dan lebih responsife.

3. Perlu dilakukan penelitian lebih lanjut agar aplikasi dapat melakukan backup data secara otomatis saat aplikasi mengalami gangguan. 


\section{DAFTAR PUSTAKA}

Dharwiyanti, S., \& Wahono, R. S. (2003). Pengantar Unified Modeling LAnguage (UML). IlmuKomputer.Com, 1-13. http://www.unej.ac.id/pdf/yanti-uml.pdf

Fania, S., Tan, R., Jurusan, S., Informatika, T., Kristen, U., \& Restoran, I. I. (2015). Sistem Manajemen Restoran X Berbasis Rich Internet Application. Jurnal Teknik Informatika Dan Sistem Informasi, 1(April), 16-21.

http://jutisi.maranatha.edu/index.php/jutisi/article/download/356/354

Indrajit, R. E., \& Djokopranoto, R. (2003). Manajemen Persediaan. Jakarta: PT Gramedia Widiasarana Indonesia.

Prabowo, R. G. M. (2016). Indeks Kepuasan Masyarakat Terhadap Pelayanan Kantor Desa Bandung Kabupaten Tulungagung. Benefit, 3(1), 75-92.

Purnama, C. (2016). Buku Pintar Pajak E-Commerce. 2(1), 159-168.

Yen, D., \& Davis, W. (1998). Rapid application development (RAD). The Information System Consultant's Handbook. https://doi.org/10.1201/9781420049107.ch32 